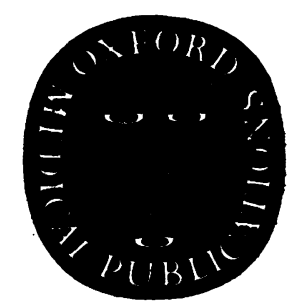

FUST PUBLISHED

\title{
The Evolution of
}

\section{MEDICAL EDUCATION in the Nineteenth Century}

\author{
CHARLES NEWMAN \\ Dean of the Postgraduate Medical School, London \\ SUMMARY OF CONTENTS
}

I MEDICAL EDUCATION IN I 800

(i) The Medical Profession in 1800 . (ii) Physicians. (iii) Surgeons. (iv) Apothecaries. (v) Methods of Education. (vi) The Teaching Institutions. (vii) The Medical Student. (viii) Postgraduate Education.

II THE REBIRTH OF SCIENCE AND THE APOTHECARIES' ACT

(i) The Rebirth of Science. (ii) Unqualified Practice. (iii) The Apothecaries' Act.

III THE EVOLUTION OF MEDICAL EDUCATION FROM WITHIN $1815-1858$

(i) The Nature of Reform. (ii) The Application of Science to Medicine-Physical Signs. (iii) Botany. (iv) Chemistry. (v) Clinical Methods in Examination Papers. (vi) Clinical Teaching. (vii) Progress in Pathology. (viii) The Curriculum. (ix) The Professions and their Education. (x) The London Medical Schools and the University of London. (xi) Provincial Schools. (xii) Improvements in Medical Schools. (xiii) Gains and Losses. (xiv) Reform at Cambridge. (xv) Reform at Oxford. (xvi) Conjoint Schemes.

IV EXTERNAL REFORM AND THE MEDICAL ACT

(i) Unqualified Practice. (ii) Wakley and the College of Surgeons. (iii) The 1834 Committee.

(iv) The Early Medical Bills. (v) Sir James Graham's Bill. (vi) The 1847 Committee.

(vii) The Intermediate Bills. (viii) The Period of Confusion. (ix) The Medical Act.

V THE SAFE GENERAL PRACTITIONER

(i) Preliminary Education. (ii) Examinations. (iii) The Preliminary Sciences. (iv) The Curriculum. (v) Apprenticeship. (vi) Art and Science. (vii) The Single Portal. (viii) The General Medical Council.

VI THE RISE OF LABORATORY MEDICINE

(i) French and German Science. (ii) London and The 'Teaching University'. (iii) Oxford.

(iv) Cambridge. (v) The Provincial Schools. (vi) The Royal Colleges. (vii) The Medical Education of Women. (viii) Postgraduate Education.

\section{2 pages 30s. net \\ OXFORD UNIVERSITY PRESS}


inis

\section{S C H U M A N}

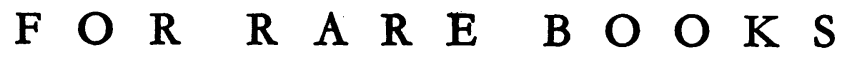
in the

\section{History of Science and Medicine}

\section{CURRENT CATALOGUES}

Number 2, New Series:

RARE MEDICAL BOOKS

Number 3, New Series:

RARE BOOKS IN THE HISTORY OF SCIENCE

List $C$ :

HISTORY OF NEUROLOGY, PSYCHIATRY, PSYCHOLOGY

SEND US YOUR DESIDERATA

WE ARE ALWAYS GLAD TO PURCHASE ENTIRE COLLECTIONS OR SINGLE ITEMS OF MERIT

Ida W. Schuman • 22 I I Broadway • New York 24 N.Y.

CABLE, ADDRESS: SCHUBOOKS 
Printed in Great Britain by Farrold and Sons Ltd, Norwich 